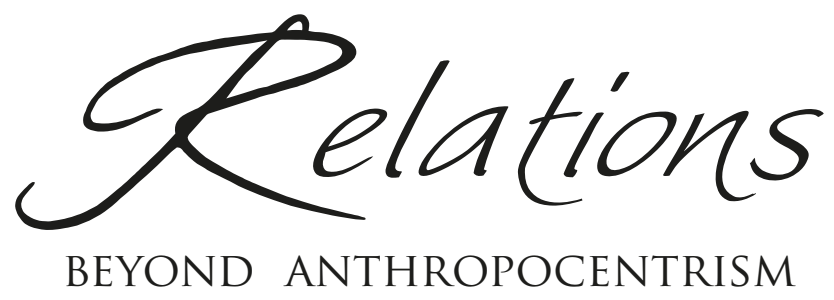

\author{
$9.1-2$ \\ NOVEMBER 2021 \\ Animals: Freedom, Justice, Welfare, \\ Moral Status, and Conflict Cases \\ Edited by Francesco Allegri
}

\author{
STUDIES \\ AND RESEARCH CONTRIBUTIONS
}

Pigs vs. Boars: The Ethics of Assisting Domesticated and Wild Animals

Beka Jalagania

The Chincoteague Ponies and What It Means To Be Free

Alexis Flower

Beyond the Fairy Tale of The Shape of Water: Reimagining the Creature

Viktorija Lankauskaite

Max Scheler e la possibilità di una nuova forma di antispecismo

Enrico R.A. Calogero Giannetto

Distributive Justice and Animal Welfare

Paola Morreale

Unitarianism or Hierarchical Approach for Moral Status?

A Very Subtle Difference

Francesco Allegri 


\section{Comments, Debates, Reports AND INTERVIEWS}

Animals and Justice: The Unfinished Journey

Paola Fossati

Author Guidelines 


\title{
The Chincoteague Ponies and What It Means To Be Free
}

\author{
Alexis Flower \\ Canisius College, Buffalo (NY) \\ DOI: https://dx.doi.org/10.7358/rela-2021-0102-flow
}

flowera@my.canisius.edu

\begin{abstract}
The Chincoteague pony swim is a cherished tradition in Chincoteague, Virginia, where noble saltwater cowboys round up wild horses to be sold at auction the next day. The island thrives off this event's economic impact, which is amplified through Marguerite Henry's series "Misty of Chincoteague", allowing the pony's fame to reach all corners of the world. The tradition is rooted in Chincoteague culture, but several different ethical aspects come into question after critical consideration. The islander's economic dependence and pride in the ponies and yearly round up act as a disguise for these ethical quandaries, through the practice of modern myth making. This paper explores concepts of breed, the state of being wild vs. free, language surrounding horses, and hidden symbols within the swims organization to uncover the covert way in which Chincoteague culture upholds colonial values.
\end{abstract}

Keywords: breed; Chincoteague ponies; colonialism; culture; ethics; modern myth; slavery; taxidermy; tourism; wild.

\section{INTRODUCTION}

Chincoteague Island is a charismatic small town with a tourist attraction that makes you feel like part of the community: the Chincoteague ponies. Growing up thirty minutes from the island, my childhood contained many visits to Chincoteague's beaches, fascination for the wild horses, and walks through the quaint "downtown". Many American small towns maintain customs established around their time of settlement, and Chincoteague is no exception. Declared "America's Happiest Seaside Town" of 2014 (Bekiempis 2014), this little island provides all the small quirks and amenities that enable its people to live slow, nostalgic lives throughout most of the year leading up to their one major event each July: the

Relations - 9.1-2 - November 2021

https://www.ledonline.it/Relations/ - Online ISSN 2280-9643 - Print ISSN 2283-3196 
Chincoteague Pony Swim. This event draws massive crowds from across the world to witness the famous stocky "ponies" swim across the Assateague Channel to reach the Chincoteague shore where they are corralled for auction. Witnessing the event several times myself, I recall the near magical experience the spectacle provides: it is easy to lose oneself in the seemingly ancient custom and prideful experience of capturing the "wild" horses.

It is clear that the Chincoteague ponies mean everything to the island town. You cannot walk down a street in Chincoteague without spotting something pony themed, whether it be the banners hung on street posts, merchandise in gift shops, or cleverly named businesses such as the "Sandy Pony Donut Shop" or the "Pony Express". Even the high school's mascot is "the ponies" (Bekiempis 2014). Yet, when you break down the components of the pony swim and the significance of the ponies' paradoxical "wild" status, the ethical relationship between the town and ponies comes into question. Islander's economic gain from the ponies is substantial, but I aim to uncover certain aspects of the culture surrounding the Chincoteague ponies that may be overlooked due to the towns' financial dependence on them.

To better understand the complex relationship the people of Chincoteague share with the local ponies, I will provide a brief historical account of Chincoteague. This history helped lay the foundation for the oppressive tendencies that evolved into the Chincoteague Pony Swim today. Another major factor contributing to the ponies' perceived value on the island is the award winning children's series, "Misty of Chincoteague". I will provide an in depth analysis of how this series has affected the people of Chincoteague by elevating the Chincoteague pony from a living being to a "piece of living history" (Bekiempis 2014) as a result of the romanticized introductory theory of the ponies to the island. It is also important to consider the terminology associated with horses, which will play a crucial role in determining the status of the Chincoteague pony, both in terms of their freedom and value to society. Finally, firsthand accounts from various members of Chincoteague society will be included to get a better understanding of the local perceptions on the importance of the Chincoteague ponies to the community and how its members justify certain practices still used in the swim today. 


\section{Chincoteague history}

Chincoteague is a 9.3 square mile sliver of island located just south of Maryland's eastern shore border. Assateague, the larger of the barrier islands, protects Chincoteague from the brunt of the Atlantic Ocean (Camagna and Cording 2004, 2). Together, these two islands have a shared history with overlapping use of the famed saltwater ponies. The Chincoteague Bay, a channel of water separating the two islands, is the setting for the celebrated pony swim. Despite the small size of the island, 2,899 people inhabit Chincoteague with $92 \%$ of its inhabitants being white according to the most recent available data (US Census Bureau 2018).

Prior to the discovery of Chincoteague Island by Italian explorer Giovanni da Verrazzano in the early 16th century (DeVincent-Hayes and Bennett 2000; Camagna and Cording 2004), Chincoteague and the surrounding barrier islands were home to a network of Native American tribes called the Assateagues, which included the tribes: Pocomoke, Annamessex, Manokin, Assateague, Kicotank, and Chincoteague. These tribes all lived under the control of the emperor of Assateague (DeVincent-Hayes and Bennett 2000, 92). By the late 1600's, European settlers began claiming the barrier islands as their own, utilizing the shore to pasture livestock (Camagna and Cording 2004, 2). In addition to stealing the Assateague's land, early settlers also enslaved them, forced miscegenation (mostly between blacks and natives), and murdered them either violently or by introducing diseases such as the small pox (Krogh N.D.). An attempt at peace was made in 1742 and a treaty was struck between the remaining Assateague tribe members and the European settlers in the area. Several accounts, however, claim that this treaty "did not work well" (DeVincent-Hayes and Bennett 2000; Camagna and Cording 2004), and most of the Native Americans were driven from the area by 1750 . By the early 1800's, about 200 people inhabited both Chincoteague and Assateague Islands, and settlers began holding periodic penning events to sort and brand animals (Camagna and Cording 2004, 4). The colonialism that had first subjugated the Native American tribes began to see its way into the lives of the Chincoteague ponies, as white Christian settlers saw this new land as their "moral obligation to conquer any people who were still living in harmony with nature" (Spiegel 1988, 16).

The first written account of the now famous pony penning appeared in a letter to a magazine in 1835 (Camagna and Cording 2004, 4). The writer described the event as an "'ancient custom' that inspired great celebration and attracted crowds from afar" (ibid.). What prompted this tradition of pony penning? There are several theories as to how

Relations - 9.1-2 - November 2021

https://www.ledonline.it/Relations/ - Online ISSN 2280-9643 - Print ISSN 2283-3196 
the ponies arrived on the islands, varying in degrees of practicality and romanticized stories. The most popular accounts include pirates who attempted to hide the ponies within the barrier islands, or Spanish galleons wrecking off the coast of Chincoteague compelling the Chincoteague Ponies to swim to shore (DeVincent-Hayes and Bennett 2000, 182; Camagna and Cording 2004, 53; Shepherd 2007; Arden 2013; Bekiempis 2014). These romanticized versions of the Chincoteague ponies arrival aids in their mythical status perceived by the islanders, which in turn transforms them from living being to historical object. The ponies' arrival story is likely much more practical than many would choose to believe, with their original owners leaving the horses on the shore to graze, allowing free pasture, fencing, and importantly, freedom from paying taxes against the livestock (DeVincent-Hayes and Bennett 2000, 183). However, this reality doesn't make for a good story, and many forms of oppression require rationalization through a backstory.

The Chincoteague pony herd is considered "wild", although the population is legally owned by the Chincoteague Volunteer Fire Department, who keeps the herd size to a manageable 150 ponies (Camagna and Cording 2004, 4; Bekiempis 2014). The herd is composed of various breeds resulting from the incorporation of outside stock, including: Paso Fino, Shetland pony, mustang, quarter horse, and Arabic ancestors (Guest 2019, 182). The Chincoteague ponies are small, but sturdy equine, and are actually horses when considering their skeletal structure (Shepherd 2007). The ponies have adapted to live in the harsh environment that the islands provide, with thick coats to protect them from the copious stinging insects in the summer and temperature drops in the winter (Camagna and Cording 2004, 53). They live mostly on marsh grass and brackish water, constituting a high salt diet, which contributes to stunting their growth (ibid.; Shepherd 2007). To offset their high salt intake, Chincoteague ponies drink about twice as much water as horses living in mainland areas, at about 20 gallons per day, making their stomachs swell and appear pregnant (ibid.).

It is important to note that there are two distinct herds found on the barrier islands. A fence separates Assateague Island, marking the territory of the northern Assateague herd who is owned by the federal government and managed by the National Park Service. These horses live a fairly undisturbed and natural life. However, the southern Chincoteague herd is "the stuff of legends", and is known worldwide as The Chincoteague ponies (Camagna and Cording 2004, 4). The fence does not only stand to demarcate the two herds in terms of ownership, but also to

Relations - 9.1-2 - November 2021

https://www.ledonline.it/Relations/ - Online ISSN 2280-9643 - Print ISSN 2283-3196 
control breeding between the two herds in an attempt to maintain purity of the Chincoteague bloodline (DeVincent-Hayes and Bennett 2000, 16). While the Assateague herd receives limited to no human intervention, the Chincoteague herd receives quite a bit of "assistance", including the introduction of new breeding stock in an effort to improve the size and appearance of the ponies. The Chincoteague ponies are rounded three times a year: once for the annual pony swim event and twice for wellness exams' including the administration of vaccines and hoof trims (Camagna and Cording 2004, 63).

The pony swim celebrated its 96th year in July 2020. What started as a rowdy local tradition of rounding up loose livestock has evolved into a globally recognized event that has defined the town of Chincoteague, as well as its people. The event has remained customary throughout the years with the distinguished role of "saltwater cowboy" often spanning multiple family generations as the brave American men who ride out on horseback to roundup the "wild" beasts of the frontier. In traditional fashion, all riders must be men from the Chincoteague Volunteer Fire Department or one of their invited guests (Camagna and Cording 2004, 50). Women have always played minor roles in the annual pony swim festivities, with the men holding major positions. "Along with looking over the horses that would be auctioned the next day, the men also courted the women present, who would wear their finest dresses" (DeVincent-Hayes and Bennett 2000, 186). Women's exclusion from handling the horses, or involvement in the festivities outside of their appearance, objectified them in a similar fashion to the ponies. Like the ponies who would later be auctioned based off of their appearance, the women of Chincoteague further enabled the white men of the island to commodify living beings that began during Chincoteague's colonialization.

\section{Misty of Chincoteague as CUltural identity}

All forms of oppression are linked together (Ko 2019). One group cannot be oppressed without the justification that comes with the oppression of another. The white male is often viewed as the pinnacle of human existence, which immediately relegates all others outside of this group as inferior. Females, indigenous groups, people of color, and animals suffer from this apparent ordering of life. If all forms of oppression are linked together, then within each society, there has to be a progression of justifications for these actions. The Misty of Chincoteague series was just what the barrier islands needed to create an untouchable, timeless perception

Relations - 9.1-2 - November 2021

https://www.ledonline.it/Relations/ - Online ISSN 2280-9643 - Print ISSN 2283-3196 
of the Chincoteague ponies - mythical creatures in their own right with a purpose to serve the island forevermore.

"The Chincoteague Volunteer Fire Department has leveraged the Misty mythology to create an industry that is arguably the most important economic driver for the island" (Guest 2019, 182). The town once relied on the seafood industry, particularly oysters, to literally keep the town afloat, but the double introduction of the first annual pony penning and Marguerite Henry's series in 1947 shifted the focus from seafood to tourism as thousands began visiting the islands to witness the famous ponies (Camagna and Cording 2004, 18). The impact of the series in conjunction with the swim created economic stability, with many islanders considering the event, "Christmas in July" (DeVincent-Hayes and Bennett 2000, 157; Bekiempis 2014). Today, over 800,000 people visit the Assateague refuge throughout the year. Additionally, a staggering 1.2-1.5 million visit the Virginia side, the island s welling to more than ten times its normal population during the roundup, swim, and auction (DeVincent-Hayes and Bennett 2000, 14; Bekiempis 2014). I argue that the island's economic dependence on the yearly roundup and related tourist attractions effectively disguises various ethical aspects concerning the yearly round up and auction.

A concept that will be utilized throughout the evaluation of Chincoteague and its ponies is modern myth making, "the means by which contradictory and complex ideological worldviews are simplified in images that naturalize their messages. Myth 'abolishes the complexity of human acts, it gives them the simplicity of essences'" (Guest 2019, 178). The ponies' mythological status both strengthens and justifies the paradoxical relationship they have with the people of Chincoteague. The ponies are "wild" yet owned. They represent the untamed chaos of nature, and Chincoteague culture upholds colonial values that seek dominion over what is wild.

Misty of Chincoteague is about a family in which the two children buy a particularly elusive and rowdy mare, Phantom, from the Chincoteague pony auction. The first book follows their relationship with Phantom as they attempt to "break" her, therefore extinguishing her free spirit and subjecting her to domestication. Phantom triumphs in her situation, refusing the imposing dominance and maintaining her wild spirit (Henry 1947). Eventually, the family decides to return her to the wild beaches of Assateague, but not before keeping her first foal, Misty, who represents the successful domination over nature and remains on Chincoteague under the family's direct control. Throughout the Misty series, this oppositional and romantic view is extended: Assateague is identified

Relations - 9.1-2 - November 2021

https://www.ledonline.it/Relations/ - Online ISSN 2280-9643 - Print ISSN 2283-3196 
as the island of "wild things" and Chincoteague is the "island of men" (Guest 2019, 180). The series clearly differentiates between wild (nature) and man (culture) and celebrates the control the round up allows over the ponies who inhabit the land - a similar dichotomy between the tribes and settlers years ago. Spiegel summarizes the average colonists view on nature: "[The] frontiersmen acutely sensed that they battled wild country not only for personal survival, but in the name of nation, race, and God, civilizing the new world meant enlightening darkness, ordering chaos, and changing evil into good" (Spiegel 1988, 16). This outlook over the domination the barrier islands experienced in the early 16th century continues covertly in many practices involving the ponies today.

The series romantic view of the ponies is most responsible for their myth creation. Henry chose to incorporate the Spanish galleon wreck as the ponies' introductory story to the shores of Assateague. Not only did she choose this romanticized version of their beginnings on the island, but she also framed their history in terms of biblical figurations when saying, "The ponies forgot the forty days and forty nights in the dark hold of the Spanish galleon" (Henry 1947, 26). This introduction that includes a biblical "time and trial" (Guest 2019, 180) is reminiscent of Noah's Ark and advances themes of Christianity, which are "historically used as a colonial tool to bolster white superiority" (Ko 2019, 10). The ponies' introduction to the island also provided a sharp contrast between wild and domestic states (Guest 2019, 180), with the ponies breaking free from the exploitative captain who originally wanted to sell and utilize the ponies for work in Peruvian gold mines. When the ponies reach the shore of Assateague, "[they] were exhausted and their coats were heavy with water, but they were free, free, free!" (Henry 1947, 45). Within the first two chapters, the ponies have gone from being transported by boat as owned merchandise ready to be sold and exploited for their labor, to escaping to their freedom. The islanders of Chincoteague celebrate this introduction story and reverse the outcome.

Another factor adding to the mythology of the Chincoteague ponies and further distinguishing them as commodities for human use is the establishment of "The Chincoteague pony" breed, brought to life through Henry's series. "A mythology of breed crystallizes history and lore, nostalgia, and the economy of Chincoteague in a version of "horse" (Guest 2019, 178). Interestingly, the desirability of the breed does not reflect purity of blood or conformity to a breed standard, but rather, that the ancestry can be traced back to the territory owned by the Chincoteague Volunteer Fire Department (ibid., 182), or that the pony is from the same herd as "Misty". Most potential buyers of a Chincoteague pony desire 
ponies that resemble "Misty", gold and white (Camagna and Cording $2004,1)$, that provide a "living link to the history, real and imagined, that is circulated on the island and crafted in Henry's books" (Guest 2019, 182). This concept of breed shaped by the myth of Henry's series creates the paradoxical relationship between the Chincoteague islanders and the ponies: "the paradox of owning what is wild" (ibid., 188).

\section{THE PARADOX OF THE WILD PONY}

In order to correctly differentiate the status of Chincoteague ponies, it is essential to understand perceptions of animals in terms of their involvement with people. As discussed, Henry's novels created the mythological breed "The Chincoteague pony", paradoxically placing them in a liminal state between wild and domestic. What then is a wild horse? Dalke suggests:

Wild horses are referred to as feral or liminal animals by the scientific community since humans interfered with natural selection by domesticating and breeding them [...] through no fault of their own these liminal animals live within the wild/domestic binary created byhumans and are subject to definition according to categories of animal identity that include breed. (Dalke 2019, 160)

The Chincoteague pony "breed" established through the Misty series is reinforced through the annual round up and auction. The ponies "no longer [live] in a wild environment or herd through which they gain identity as part of a group" (ibid., 162), but rather exist in a liminal state, prized for their "wild" status but gathered for their submissive tendencies and mythological connections. This creates problems not only through disrupting the way the ponies derive their identity, but also to the horse's place in the human perceptual hierarchy (ibid.), firmly creating an anthropocentric situation. Ironically, once the Chincoteague ponies are sorted for auction, potential buyers seek their submissive, gentle nature to allow for easy domestication, training, and the possibility to use them for whatever human ends desired (Dalke 2019, 162; Guest 2019, 177), contradictory to the unpredictability that is valued in a wild horse. "In effect, breed works to create equine bodies as cultural constructs that correspond to human desire, use, and imaginative resonance" (Dalke 2019, 167). The Chincoteague pony, then, successfully acts as a catalyst for speciesism, and in effect, the hierarchical nature of white supremacy.

The paradoxical situation of the Chincoteague ponies is further clarified when compared to human constructs. When considering domesticated animals, an animal breed is considered a sub species, similar to

Relations - 9.1-2 - November 2021

https://www.ledonline.it/Relations/ - Online ISSN 2280-9643 - Print ISSN 2283-3196 
a human race (Dalke 2019, 170; Renton 2019, 15). If this metaphor is extended, the situation of the Chincoteague ponies can be visualized as a form of racism and colonialism. Following postcolonial scholarship, these contradictory ideas about "humanness and animality shape the racist belief in Western civilized superiority and white normativity" (Deckha 2018). Deckha continues:

Racist narratives about colonized peoples as 'wild', closer to nature, and subhuman - bolstered by scientific assertions about the bestial biological and physiognomic resemblances between nonwhites and animals - enabled European metropoles to be constituted as civilized and modern and whiteness to become the exemplar of humanity. (ibid.)

The Chincoteague pony's breed being grounded in the romantic and mythical constructs of Henry's series succinctly reflects the origin and heritage story of the island itself, further cementing their fate on the island and allowing its inhabitants to continue with "white ignorance" (Harper 2010) or the unconscious participation in white privilege that allows taking advantage of others. The islands economic dependence and cultural identity constructed through the ponies proliferates the ignorance found in many engagements involving the horses. Examination of several examples helps shed light on some of these ethical oversights.

\section{ETHICAL CONCERNS OF THE Chincoteague PONy SWIM}

Anthropocentric organizations of power cause animals to be viewed not as beings in their own right, but rather, as "passive objects of its dominion" (Hansen 2012, 223). This power structure fuels many circumstances in Chincoteague framing the ponies, and many connections in their treatment can be made to racist tendencies and, at times, slavery. "Nonhuman is like nonwhite, it implies a lack of something" (Kirksey 2010) - here we find that the category of "nonhuman" is grounded in human exceptionalism, which itself is hierarchical and contains elements of racism and colonialism that enhances this notion of white supremacy. In the following paragraphs I will assess various ethical dilemmas the ponies experience during the annual roundup that follow them through the duration of their lives, and at times, after death. The roundup marks the end of their "freedom", and introduces them to slavery.

And just as they have done so many pony swim days past, men on horses gallop hard alongside the approaching ponies, cracking whips to scare rebels who dare to stray from the string $[\ldots]$ as they approach the shore, their water matted manes and tails slapping back and forth, as if they were

Relations - 9.1-2 - November 2021

https://www.ledonline.it/Relations/ - Online ISSN 2280-9643 - Print ISSN 2283-3196 
trying to break free from a tyrannical bridle [...]. Those paints, with their big patches, are sure to fetch a high price at auction the next day. (Bekiempis 2014)

This excerpt was taken from a Newsweek article printed in 2014, by Victoria Bekiempis, a writer visiting Chincoteague and witnessing the pony swim for the first time. Her language alone alludes to many dominant tones. Men ride horses cracking whips to scare rebels. The ponies show obvious signs of distress and Bekiempis even goes as far to comment on their apparent "trying to break free from a tyrannical bridle". All of these images, including preferential physical characteristics, lead to their impending future as a commodity on auction day. This scene marks the beginning of the ponies transition into subjugation and slavery.

When interviewing a young member of the Chincoteague Volunteer Fire Department about the pony swim, he comments: "The swim is great. This place gets so busy, and you know, the Fire Department makes a killing from it, which we need to survive". His response is common throughout Chincoteague and proves the events social and economic impact on the community. However, the comment also serves to "naturalize the means by which the wild is subdued to serve the ends of civilization" (Guest 2019, 185). Chincoteague locals' dependence and pride of the tradition further serves as justification for many ethical dilemmas that involve the ponies.

Once the roundup is complete, the ponies are corralled at the Chincoteague fair grounds where they are inspected by veterinarians and prepared for the next day's auction. Come auction day, around 90 ponies, mostly young colts, will be auctioned (Camagna and Cording 2004, 7). Many Chincoteague locals recite a rendition of this line when asked about the young's separation from their mothers: "While it may seem cruel to separate the colts from their mothers, the event actually occurs about the same time mother nature signals the mares to push the babies off on their own anyways" ( $\mathrm{ibid}$.). This sentiment, while true for some, is not universal and ignores the fact that animals develop strong bonds, even emotions recognized as love, for members of their species and within their families (Spiegel 1988, 44). As mentioned, horses gain identity and their place in the world through their relationship to a herd (Dalke 2019, 162), and when members of this herd are removed, social relationships can become disrupted. I asked a Chincoteague local of 25 years to describe the ponies appearance during their hold in the corral on the day of auction: "You know, they seem calm, that's a Chincoteague Pony for ya". She then trails off... "Well, it is sad when they come to take the babies away from the moms. They all start whinnying and trotting around". Her response is

Relations - 9.1-2 - November 2021

https://www.ledonline.it/Relations/ - Online ISSN 2280-9643 - Print ISSN 2283-3196 
conflicted, confident in her assessment of the Chincoteague pony disposition, but then dispirited when she admitted her emotions regarding the parent and child's separation, perhaps recognizing the emotional response similar to that in humans - distress. Local's attitudes about this separation are mirrored in Henry's novels. During the auction scene within "Misty of Chincoteague", Maureen, the sister of the sibling pair who buy Phantom, is outwardly troubled by the colts separation from their mother. The fire chief comforts her by responding "Colts got to grow up some time", explaining that it is natural for "a mare to tell her youngster to rustle his own living" and "separating them from their mothers is the kindest way we know how to teach them" (Henry 1947, 106; Guest 2019, 185). This justification resonates within the local community, diminishing emotions felt toward the clearly recognizable signs of distress and grief shown by the mares and colts. In her assessment of comparing animal conditions to that of slavery, Spiegel comments, "One of the most tragic aspects of life as a slave comes about through the destruction of the family, and in a larger sense, the social structure" (Spiegel 1988, 43).

Another occurrence the Chincoteague ponies are subjected to (as well as other various "wild" horses such as mustangs in the West), is the concept of "breaking". This is not a unique term utilized by the locals, but still provides insight to the perceived status of the ponies as inferior. "Nomenclature can serve to oppress or empower, and such is highly revealing of the attitudes of those who use particular terms" (Hurn 2012, 218). Once captured through the round up, sold at auction, and adjusting to their new home, Chincoteague ponies then "suffer what all horses must in order to be in service to humans - 'breaking in' to harness and saddle, physical confinement and control of his movements" (Hansen 2012, 212). While this term can also apply to domesticated horses, it takes a more literal meaning here, considering the ponies are taken from their wild, free lifestyle to one of control: removing the chaos and replacing it with a civilized figure in line with colonial standards (Spiegel 1988, 87). Therefore, when breaking a Chincoteague pony, "we actually do break her. We break her spirit, bend her to our will, make her a subordinate and subservient servant" (ibid., 34), which is one of the most enticing and central concepts in the Misty series. Again, we see man overpowering nature, "allowing human exceptionalism to justify the utilization and exploitation of other species who are deemed different and, in many important respects, inferior" (Hurn 2012, 202). However, the Chincoteague ponies oppression does not end at their new home, but indeed follows them into death.

Misty, the most famous pony on the island of Chincoteague, died in 1972. Her body was preserved through taxidermy and can still be viewed

Relations - 9.1-2 - November 2021

https://www.ledonline.it/Relations/ - Online ISSN 2280-9643 - Print ISSN 2283-3196 
today as a permanent exhibit (and reminder) at the Museum of Chincoteague on the island next to the fairgrounds. Her daughter, Stormy, is preserved alongside her (Camagna and Cording 2004, 8; Bekiempis 2014). To Aph Ko, taxidermy is a "covert symbol of white supremacy". She argues that:

Taxidermy functions within the realm of white supremacist thought and attitude: 'Taxidermy is understood by some as the emblem of the very values that drove the imperialist spirit: dominion, courage, vigor, undaunted determination, triumph over the "untamed", and eventual victory of patriarchal values. (Ko 2019, 50)

Following with this ideology:

Taxidermy may be conceptualized as a sign system inclusive of but not restricted to the literal stuffing of skins that produces a continually rearticulating network of signs that manipulate the categories of humans and animals, culture and nature, and life and death inthe service of white supremacy. (ibid., 58)

Misty and her daughter Stormy were mythical icons captured both figuratively and literally, through Henry's novels, serving as models for the domination of nature that had taken place on the island since colonial times. Accounts read, "She is stuffed and displayed at the Museum of Chincoteague in all her white gold grandeur" (Bekiempis 2014), and "stuffed and mounted for everyone to see" (Camagna and Cording 2004, 21), tokenizing Misty and therefore "projecting a racialized power fantasy" (Ko 2019, 59) onto the commodified object that she has become. White supremacy relies upon zoological ideas to bolster its power, and the zoological racial order is the foundation towards establishing its dominion (ibid., 38). The culture of Chincoteague, albeit perhaps under the fog of white ignorance and capitalism, has remained covertly stuck in colonial times, utilizing Assateague tribes land and people for societal gain in the past, to the Chincoteague ponies utilized in the present.

\section{Closing Remarks}

The Chincoteague Pony Swim is a cherished island tradition. It is clear that the citizens of Chincoteague recognize their economic dependence on the ponies and are extremely proud of the attention the "Misty of Chincoteague" series provides for the island. However, the question needs to be asked - do these realities outweigh the ethical concerns of the ponies and further justify the forms of exploitation discussed above? Is the pony

Relations - 9.1-2 - November 2021

https://www.ledonline.it/Relations/ - Online ISSN 2280-9643 - Print ISSN 2283-3196 
swim really in the best interest of the Chincoteague ponies or merely meeting anthropocentric needs? (Dalke 2019, 172). "Arluke and Sanders argue that all animals 'are given a cultural identity as people try to make sense of them, understand them, use them, or communicate with them"' (ibid., 160). In the case of the Chincoteague ponies, much of their cultural identity stems from the Misty series, which further exacerbates the locals continued justification for collecting and commodifying them. Garcia perfectly summarizes the Chincoteague ponies relationship with the island:

We miss the ways in which animality and racialization, nature and culture, have long mutually shaped each other. The same logics of classification and hierarchies of differencethat govern human mastery over non humans are at work in projects of coloniality and macis. (Garcia 2019)

What happens when we refuse to acknowledge connections? I do not believe the people of Chincoteague are tyrannical beings driven to conquer and control all the ponies on Chincoteague, or even that the ponies who are auctioned end up living miserable lives. However, I think it is important to note that all forms of oppression are interconnected, and partaking in actions and traditions that cause concern in one species, should be equally considered in another. Freedom is an inherently "American" right, yet many seem to struggle to maintain their freedom, or are constantly having it taken away. So, then, what does it mean to be free?

All eyes are trained on the shoreline as spectators anticipate the return pony swim when the herd is restored to freedom on Assateague island. (Camagna and Cording 2004, 51)

\section{REFERENCES}

Arden, Amy. 2013. "It Happened Here: Chincoteague, Va.: Saltwater Cowboys Round Up Wild Island Ponies". American Cowboy 20: 40. https://www. americancowboy.com/2013/07/25/it-happened-here-chincoteague-va/

Bekiempis, Victoria. 2014. "The Wild Ponies of Chincoteague Island; Chincoteague Is Overrun by Feral, Swimming Ponies. And It's a Wondrous Thing to Behold”. Newsweek 163 (16). https://www.newsweek.com/wild-ponieschincoteague-island-276678

Camagna, Dorothy, and Jennifer Cording. 2004. Chincoteague Revisited: A Sojourn to the Chincoteague and Assateague Islands. Richmond (VA): Oaklea Press.

Dalke, Karen. 2019. "Mustang, Wild Horse or Breed? Reflections of American Culture". In Horse Breeds and Human Society: Purity, Identity and the Making of the Modern Horse, edited by Kristen Guest and Monica Mattfield, 159-176. Abingdon: Routledge.

Relations - 9.1-2 - November 2021

https://www.ledonline.it/Relations/ - Online ISSN 2280-9643 - Print ISSN 2283-3196 
Deckha, Maneesha. 2018. "Postcolonial”. In Critical Terms for Animal Studies, edited by Lory Gruen, 280-293. Chicago: The University of Chicago Press.

DeVincent-Hayes, Nan, and Bo Bennett. 2000. Chincoteague and Assateague Islands. Charleston (SC): Arcadia Publishing.

García, Maria E. 2019. "Death of a Guinea Pig”. Environmental Humanities 11: 351-372. https://doi.org/10.1215/22011919-7754512

Guest, Kristen, and Monica Mattfeld. 2019. "Wild at Heart: The Chincoteague Pony and the Paradox of Feral 'Breed'". In Horse Breeds and Human Society: Purity, Identity and the Making of the Modern Horse, edited by Kristen Guest and Monica Mattfield, 177-192. Abingdon: Routledge.

Hansen, Natalie C. 2012. "Horse Talk: Horses and Human(e) Discourses". In Speaking for Animals: Animal Autobiographical Writing, edited by Margo DeMello, 207-229. New York: Routledge.

Harper, Amie B. 2010. “Race as a 'Feeble Matter' in Veganism: Interrogating Whiteness, Geopolitical Privilege, and Consumption Philosophy of 'Cruelty-Free' Products”. Journal for Critical Animal Studies 8: 1-23.

Henry, Marguerite, and Wesley Dennis. 2006. Misty of Chincoteague. New York: Aladdin Paperbacks.

Hurn, Samantha. 2012. Humans and Other Animals: Cross-Cultural Perspectives on Human-Animal Interactions. London: Pluto Press.

Kirksey, S. Eben, and Stefan Helmreich. 2010. "The Emergence of Multispecies Ethnography”. Cultural Anthropology 25:545-576. https://doi.org/10.1111/ j.1548-1360.2010.01069.x

Ko, Aph. 2019. Racism as Zoological Witchcraft: A Guide for Getting Out. Brooklyn (NY): Lantern Books.

Krogh, Matthew. N.D. A Community Gone: The Eastern Shore Natives. Eastern Shore of VA Network. http://www.esva.net/ghotes/Matthew/ES\%20Indians.htm

Renton, Kathrin. 2019. "Defining 'Race' in the Spanish Horse: The Breeding Program of King Philip II". In Horse Breeds and Human Society: Purity, Identity and the Making of the Modern Horse, edited by Kristen Guest and Monica Mattfield, 13-26. Abingdon: Routledge.

Shepherd, Misty. 2007. “An Island's Living History”. Grit. Rural American KnowHow. https://www.grit.com/animals/an-islands-living-history/

Spiegel, Marjorie. 1988. The Dreaded Comparison: Human and Animal Slavery. New York : Mirror Books.

U.S. Census Bureau. 2018. "American Community Survey 5-Year Estimates”. Census Reporter Profile Page for Chincoteague, VA. http://censusreporter. org/profiles/16000US5116512-chincoteague-va/ 